\title{
PENGARUH GLOBALISASI TERHADAP KENAKALAN REMAJA DI DESA SIDOMUKTI KECAMATAN MAYANG KABUPATEN JEMBER
}

\author{
J. Agung Indratmoko \\ IKIP PGRI Jember \\ Email : johanesagung.03@gmail.com
}

Naskah diterima: 09/08/2017 revisi: 22/09/2017 disetujui: 26/10/2017

\begin{abstract}
Abstrak
Studi penelitian ini didahului dengan timbulnya suatu permasalahan bahwa, adakah pengaruh globalisasi terhadap kenakalan remaja di desa Sidomukti. Adapun tujuan dari penelitian ini adalah untuk membuktikan adanya pengaruh globalisasi terhadap kenakalan remaja. Adapun yang menjadi variabel dalam penelitian ini adalah globalisasi dengan kenakalan remaja. Sedangkan untuk memperoleh data konkrit dalam penelitian ini menggunakan metode angket, metode interview, metode dokumenter, dan metode observasi yang kemudian dalam pengolahan data untuk memecahkan permasalahan tersebut diatas menggunakan analisa statistik dan rumus Chi Kuadrat yaitu dengan memperoleh hasil $x^{\mathbf{z}}$ tabel $=3,841$ dengan taraf signifikasi $5 \%$, dan $x^{2}$ hasil perhitungan $=26,38$, sehingga $x^{2}$ hasil perhitungan lebih besar daripada $x^{2}$ tabel taraf signifikansinya. Dari hasil analisa statistik tersebut ternyata dapat disimpulkan antara globalisasi dengan kenakalan remaja di desa Sidomukti, ada pengaruh. Pengaruhnya sebagai berikut: $x^{2}=26,38: K K=0,456$ tergolong kategori sedang.
\end{abstract}

Kata kunci: Globalisasi, Kenakalan Remaja

\section{PENGARUH GLOBALISASI TERHADAP KENAKALAN REMAJA DI DESA SIDOMUKTI KECAMATAN MAYANG KABUPATEN JEMBER}

\begin{abstract}
This Study research is previwed by the rising a problem is there the globalization influence forwarding of the naughtyness of teens in the Sidomukti village.The purpose of this research is to proved the globalization influence forwading the naughtyness of teens. In the other side to get the corcrete data in this research using angket method, interview method,dokumenter method and observation method and than in data solving for the solving data above using statistik analysis with the formula Chi Quadrat, namely with getting $x^{2}$ table $=3,841$ with significance $5 \%$ and $x^{2}$ result calculation $=26,38$, so $x^{2}$ result calculation is bigger than $x^{2}$ grade significance grade. From the result of the statistic analysis can be summarized between globalization againt the naughtyness of teen in Sidomukti Village, There is an influence. The influence is $=26,38: K K=0,456$ grouped usual catagory.
\end{abstract}

Keywords: GlobalizationA; influence forwarding of the naughtyness of teens 


\section{PENDAHULUAN}

Globalisasi merupakan hal yang sangat berpengaruh terhadap perkembangan potensi dan kepribadian anak atau remaja saat ini. Globalisasi merupakan kondisi dimana jarak antara negara yang satu dengan negara lain sudah tidak ada batas lagi. Dimana aturan, budaya, norma dan lain sebagainya sudah mulai memudar ( $\mathrm{M}$. Waters, 2004 ). Apalagi pengaruh globalisasi sosial budaya pada era teknologi informasi dan komunikasi yang paling rentan adalah remaja,sebab remaja bisa mengakses sumber dari internet dan sebagainya secara langsung. Bila permasalahan ini tidak dikondisikan dengan baik dan benar bisa menimbulkan perilaku yang menyimpang.

Berdasarkan penjelasan tersebut
maka perlu remaja mendapatkan pengawasan dari pihak Orang tua, Guru, dan Masyarakat. Diantara ketiganya Orang tualah yang memegang peranan penting dalam menjaga sikap dan perilaku anak atau remaja, agar tidak terjadi perilaku yang menyimpang yang disebut dengan kenakalan remaja.Jadi kenakalan remaja merupakan perbuatan yang menimbulkan keonaran dalam masyarakat ( PaulMoedikdo, 1987 ), sehingga dapat merugikan diri sendiri, keluarga, lembaga sekolah dan masyarakat.

\section{Globalisasi}

Globalisasi adalah proses dimana berbagai peristiwa, keputusan dan kegiatan dibelahan dunia yang satu dapat membawa konsekuensi penting bagi berbagai individu dan masyarakat dibelahan dunia yang lain (A.G McGrew, 1992). Selanjutnya menurut M. Waters, 2004 globalisasi merupakan sebuah proses sosial dimana halanganhalangan bersifat geografis pada tatanan sosial dan budaya semakin menyusut dan setiap orang kian sadar bahwa mereka semakin dekat satu sama lainnya.

Berdasarkan penjelasan diatas peneliti dapat menyimpulkan bahwa globalisasi merupakan gejala yang mempengaruhi banyak hal dan tidak bisa dielakan lagi bahwa kehidupan diubah ketika globalisasi masuk dalam kehidupan masyarakat dari tatanan sosial budaya dan dunia seakan tanpa batas, sehingga globalisasi dapat menimbulkan beberapa dampak di antaranya adalah sebagai berikut : berkembangnya teknologi informasi dan komunikasi, pola fikir masyarakat yang semakin maju, kebudayaan instan, memudarnya nilai-nilai budaya lokal dan bergesernya nilai-nilai budaya lokal yang menimbulkan anomi.

Menurut Selo Soemardjan globalisasi adalah terbentuknya sistem organisasi dan komunikasi antarmasyarakat diseluruh dunia untuk mengikuti sistem dan kaidah-kaidah yang sama. Sedangkan menurut Jhon Huckle globalisasi adalah suatu proses dimana kejadian, keputusan, dan kegiatan disalah satu bagian dunia menjadi suatu konsekuensi yang signifikan bagi individu dan masyarakat di daerah yang jauh. Sementara itu, Albrow mengemukakan bahwa globalisasi adalah keseluruhan proses dimana manusia di bumi ini dimasukkan kedalam masyarakat dunia tunggal, masyarakat global.

Berdasarkan penjelasan diatas penulis dapat menyimpulkan bahwa globalisasi merupakan meningkatnya hubungan dan kesalingtergantungan antara warga masyarakat dunia. Dengan kata lain, globalisasi mengacu pada kenyataan bahwa kita hidup dalam satu dunia, dimana tindakan-tindakan kita mengandung konsekuensi bagi orang lain, dan peristiwaperistiwa yang terjadi dibelahan dunia lain mengandung konsekuensi bagi kita. Globalisasi dewasa ini mempengaruhi kehidupan orang disemua negara, kaya ataupun miskin, yang mengubah tidak saja sistem global tetapi juga penghayatan kehidupan sehari-hari. Beberapa hal yang merupakan dampak globalisasi dalam bidang sosial budaya:

\section{Berkembangnya Teknologi Informasi Dan Komunikasi}

Teknologi merupakan kemampuan teknik yang berlandaskan pengetahuan ilmu eksakta yang bersandarkan ilmu teknik. Komunikasi adalah menyampaikan gagasan, ide atau berita dari pihak pertama kepada 
pihak kedua.Komunikasi merupakan kebutuhan pokok bagi setiap manusia baik bagi pertumbuhannya maupun bagi keperluan kehidupannya.Informasi merupakan penerangan, keterangan, pemberitahuan kabar atau berita.Pada abad saat ini, penyampaian informasi sudah semakin canggih, dimulai dari komunikasi sederhana sampai pada komunikasi elektronik.Karena didukung oleh ilmu pengetahuan dan teknologi yang selalu berkembang, sehingga mempermudah kita dalam melakukan pertukaran informasi dalam segala hal.

Pengertian teknologi menurut Haag dan Keen (1996:3) adalah seperangkat alat yang digunakan untuk membantu dalam melakukan tugas-tugas yang berhubungan dengan pemrosesan informasi. SedangkanMenurut Martin (1999) teknologi informasi tidak hanya terbatas pada teknologi komputer ( perangkat keras dan perangkat lunak ) yang digunakan untuk memproses dan menyimpan informasi, melainkan juga mencakup teknologi komunikasi untuk mengirimkan informasi.Menurut Williams dan Sawyer (2003) teknologi informasi adalah penggabungan komputasi ( komputer dengan jalur komunikasi berkecepatan tinggi yang membawa data, suara, dan video ). Teknologi informasi adalah gabungan antara teknologi komputer dan teknologi komunikasi.

Komunikasi ialah kegiatan saling berbagi pendapat, informasi, pesan antara berbagai pihak pada suatu waktu dan tempat tertentu.(Aries Setya Nugraha ,2004:4).Teknologi informasi ialah teknologi pengolahan dan penyebaran data dengan menggunakan perangkat keras (hardware) dan perangkat lunak (software).

Berdasarkan penjelasan diatas penulis dapat menyimpulkan bahwa teknologi informasi dan komunikasi merupakan gagasan, berita atau kabar yang diperoleh dari alat teknologi baik itu perangkat keras maupun perangkat lunak, serta dengan semakin berkembangnya teknologi informasi dan komunikasi memungkinkan seseorang berkomunikasi dan mencari pengetahuan dengan efektif dan efisien. Seseorang akan lebih mudah mendapatkan informasi baik itu didalam negeri maupun diluar negeri, semua itu bisa diperoleh dengan menggunakan teknologi informasi yang semakin maju diera globalisasi.

Beberapa perubahan yang terjadi sebagai dampak teknologi informasi seperti pada Perbankan berubah drastis sejak ditemukannya kartu kredit, ATM, perbankan melalui internet, bahkan melalui telepon selular. Teknologi informasi meluas hingga ke dunia pendidikan. Guru dan murid memiliki kesempatan menjajal berbagai perangkat lunak untuk meningkatkan efektivitas kegiatan belajar mengajar di sekolah dan mendapatkan informasi melalui internet. Para ilmuwan memanfaatkan teknologi informasi untuk mengumpulkan data secara otomatis demi menemukan pemecahan terhadap masalah lingkungan dan manusia. Dan para dokter menjadi terbantu dalam mendiagnosa penyakit pasien dan menemukan langkah penyembuhannya.

Dari berbagai perubahan yang ada, terdapat beberapa alat yang digunakan untuk memperoleh informasi seperti: Televisi; Radio; Telepon; Komputer; Internet. Dan dari menjamurnya berbagai alat tersebut dalam kalangan masyarakat ternyata memicu munculnya berbagai masalah etika antara lain adalah : Menyangkut privasi seseorang; Keamanan dan ketepatan data dan informasi; Perubahan cara bekerja; Penggunaan informasi dengan semestinya; Undang-undang hak cipta; Masalah lingkungan dan kesehatan.

\section{Pola Fikir Masyarakat Yang Semakin Berkembang}

Pengetahuan adalah segala sesuatu yang diketahui atau kepandaian yang dimiliki oleh seseorang.Pembangunan nasional telah memberi kesempatan yang seluas-luasnya kepada masyarakat Indonesia untuk memperoleh pendidikan mulai dari TK, SD, SMP, SMA, dan perguruan Tinggi.Hal itu tampak jelas dari peningkatan taraf kecerdasan dan kepandaian sehingga 
mampu menyesuaikan diri terhadap lingkungannya yang pada akhirnya berdampak pada kemampuan memproduksi berbagai jenis barang dan jasa, seperti peralatan hidup yang berteknologi canggih. Dari berbagai pengetahuan banyak hal, masyarakat yang dulunya masih berpola fikir tradisional sekarang mulai berkembang menjadi masyarakat yang lebih modern.

\section{Budaya Instan}

Budaya instant adalah suatu istilah yang digunakan oleh manusia untuk menjuluki keadaan dunia jaman sekarang.Edward Burnett Tylor pada abad ke-19 menyatakan bahwa budaya atau kebudayaan merupakan suatu keseluruhan yang kompleks yang mencakup pengetahuan, keyakinan, kesenian, moral, hukum, adat-istiadat, dan segala kemampuan dan kebiasaan yang diperoleh manusia sebagai anggota masyarakat.Setelah melihat definisi ini kita dapat menyimpulkan bahwa instant dikatakan sebuah budaya karena hal itu sudah menjadi sebuah kebiasaan dalam masyarakat.Kebiasaan manusia yang ingin segala sesuatu diperoleh secara instant ini merupakan dampak dari tuntutan jaman yang semakin kompleks, sebab itu tuntutan ini akhirnya orang-orang berusaha menciptakan alat-alat atau teknologiteknologi yang dapat membantu manusia dalam memperoleh sesuatu secara cepat.

Ada banyak perubahan pesat yang terjadi sekarang membuat dalam diri manusia timbul ketidakseimbangan antara akalbudi modern yang bersifat praktis dan cara berpikir teoritis. Muncul pula ketidak seimbangan antara pemusatan perhatian pada kedayagunaan praktis dan tuntutan moral suara hati, antara syarat-syarat kehidupan bersama dan tuntutan pemikiran pribadi.

Ketidakseimbangan yang terjadi tersebut dapat kita lihat secara nyata di kehidupan kita.Budaya instant termasuk dalam ketidakseimbangan tersebut. Orang lebih mementingkan hasil dari pada proses. Kita tidak bisa menyangkal bahwa kita terjebak dalam arus budaya instant, banyaknya produk yang bersifat instant yang bisa kita temui di mana saja entah itu berupa makanan, pakaian, alat komunikasi, dan teknologi yang semakin canggih dan menawarkan kenyamanan bagi para pemakainya merupakan salah satu faktor utama dari munculnya budaya instant. Tanpa kita sadari hal ini sangat mempengaruhi mentalitas kita yang selalu ingin segala sesuatunya diperoleh secara instant dan bahkan menggunakan cara-cara yang menyimpang.Inilah yang dinamakan dengan mentalitas instantisme. Memudarnya Nilai-Nilai Budaya Lokal

Gaya hidup yang individualistis yang merupakan kepentingan diri sendiri sehingga kesetiakawanan sosial semakin hilang, (M. Waters). Seseorang lebih mementingkan kenikmatan sesaat sehingga norma dan aturan sudah tidak dihiraukan lagi. Memudarnya semangat gotong royong, solidaritas, kepedulian dan kesetiakawanan sosial sehingga dalam keadaan tertentu seperti musibah, kecelakaan, dan sakit hanya ditangani oleh sebagian kecil orang.Akibatnya, unsur kebersamaan dan kekeluargaan semakin berkurang dan mulai hilang. Sudah banyak dari sebagian orang meniru pola hidup orang barat salah satunya adalah tata cara berpakaian yang identik dengan cara berpakaian yang fullgar dan glamor, sehingga tata cara berpakaian orang timur ( Indonesia ) sudah tidak menjadi tradisi yang harus dilestarikan.

\section{Pergeseran Nilai-nilai Budaya yang Menimbulkan Anomi}

Masuknya unsur-unsur globalisasi yang sangat gencar dalam waktu yang relatif singkat akan mengakibatkan terjadinya perubahan sosial budaya secara susulmenyusul. Sementara itu sistem nilai dan norma yang ada dalam kehidupan masyarakat tidak siap mengantisipasi terjadinya perubahan-perubahan itu. Akibatnya, masyarakat menjadi kebingungan (anomi). Kebingungan masyarakat terhadap terjadinya perubahanperubahan nilai budaya tidak akan berlangsung lama jika masyarakat tersebut dapat menyesuaikan dengan cepat. Hal ini 
dikhawatirkan akibat anomi ini adalah nilainilai budaya yang telah ada menjadi rusak dan dipengaruhi oleh budaya luar.

\section{Pengertian Kenakalan Remaja}

Fuad Hasan mengatakan bahwa kenakalan ialah perbuatan anti sosial yang dilakukan oleh anak atau remaja yang apabila dilakukan oleh orang dewasa diartikan sebagai kejahatan. Kenakalan merupakan tingkah laku secara ringan yang menyalahi norma dan hukum yang berlaku dalam masyarakat. W.J.S. Poerwadarminta menyatakan bahwa kenakalan ialah perbuatan kurang baik dan mengganggu masyarakat.

Sedangkan remaja adalah suatu usia dimana individu menjadi terintegrasi kedalam masyarakat dewasa, suatu usia dimana anak tidak merasa bahwa dirinya berada dibawah tingkat orang yang lebih tua melainkan merasa sama, (Hurlock, 1991). Sedangkan menurut Hasan Basri (2004: 4), Remaja adalah mereka yang meninggalkan masa kanak-kanak yang penuh dengan ketergantungan dan menuju masa pembentukan tanggung jawab. W.J.S. Poerwadarminta mengatakan bahwa remaja adalah usia mulai dewasa. Berdasarkan penjelasan tersebut diatas dapat penulis simpulkan bahwa remaja adalah suatu usia dimana individu menjadi terintegrasi kedalam masyarakat dewasa dan telah meninggalkan masa kanak-kanak yang penuh dengan tanggung jawab.

Kenakalan remaja adalah semua perbuatan yang merupakan penyelewengan norma-norma kelompok tertentu yang menimbulkan keonaran dalam masyarakat yang dilakukan oleh anak muda, (Ary $\mathrm{H}$. Gunawan).Sedangkan menurut Sudarsono, (2008: 11) kenakalan remaja ialah perbuatan, kejahatan, pelanggaran yang dilakukan oleh anak remaja yang bersifat melawan hukum, anti sosial, anti susila, dan menyalahi norma agama. Menurut B. Simanjuntak kenakalan remaja adalah perbuatan dan tingkahlaku yang melanggar terhadap norma-norma hukum pidana dan pelanggaran terhadap kesusilaan yang dilakukan oleh anak-anak. Pola Fikir Masyarakat Yang Semakin Berkembang

Pengetahuan adalah segala sesuatu yang diketahui atau kepandaian yang dimiliki oleh seseorang.Pembangunan nasional telah memberi kesempatan yang seluas-luasnya kepada masyarakat Indonesia untuk memperoleh pendidikan mulai dari TK, SD, SMP, SMA, dan perguruan Tinggi.Hal itu tampak jelas dari peningkatan taraf kecerdasan dan kepandaian sehingga mampu menyesuaikan diri terhadap lingkungannya yang pada akhirnya berdampak pada kemampuan memproduksi berbagai jenis barang dan jasa, seperti peralatan hidup yang berteknologi canggih. Dari berbagai pengetahuan banyak hal, masyarakat yang dulunya masih berpola fikir tradisional sekarang mulai berkembang menjadi masyarakat yang lebih modern.

\section{Budaya Instan}

Budaya instant adalah suatu istilah yang digunakan oleh manusia untuk menjuluki keadaan dunia jaman sekarang.Edward Burnett Tylor pada abad ke-19 menyatakan bahwa budaya atau kebudayaan merupakan suatu keseluruhan yang kompleks yang mencakup pengetahuan, keyakinan, kesenian, moral, hukum, adat-istiadat, dan segala kemampuan dan kebiasaan yang diperoleh manusia sebagai anggota masyarakat.Setelah melihat definisi ini kita dapat menyimpulkan bahwa instant dikatakan sebuah budaya karena hal itu sudah menjadi sebuah kebiasaan dalam masyarakat.Kebiasaan manusia yang ingin segala sesuatu diperoleh secara instant ini merupakan dampak dari tuntutan jaman yang semakin kompleks, sebab itu tuntutan ini akhirnya orang-orang berusaha menciptakan alat-alat atau teknologiteknologi yang dapat membantu manusia dalam memperoleh sesuatu secara cepat.

Ada banyak perubahan pesat yang terjadi sekarang membuat dalam diri manusia timbul ketidakseimbangan antara akalbudi modern yang bersifat praktis dan cara berpikir teoritis. Muncul pula ketidak seimbangan antara pemusatan perhatian 
pada kedayagunaan praktis dan tuntutan moral suara hati, antara syarat-syarat kehidupan bersama dan tuntutan pemikiran pribadi.

Ketidakseimbangan yang terjadi tersebut dapat kita lihat secara nyata di kehidupan kita.Budaya instant termasuk dalam ketidakseimbangan tersebut. Orang lebih mementingkan hasil dari pada proses. Kita tidak bisa menyangkal bahwa kita terjebak dalam arus budaya instant, banyaknya produk yang bersifat instant yang bisa kita temui di mana saja entah itu berupa makanan, pakaian, alat komunikasi, dan teknologi yang semakin canggih dan menawarkan kenyamanan bagi para pemakainya merupakan salah satu faktor utama dari munculnya budaya instant. Tanpa kita sadari hal ini sangat mempengaruhi mentalitas kita yang selalu ingin segala sesuatunya diperoleh secara instant dan bahkan menggunakan cara-cara yang menyimpang.Inilah yang dinamakan dengan mentalitas instantisme. Memudarnya Nilai-Nilai Budaya Lokal

Gaya hidup yang individualistis yang merupakan kepentingan diri sendiri sehingga kesetiakawanan sosial semakin hilang, (M. Waters). Seseorang lebih mementingkan kenikmatan sesaat sehingga norma dan aturan sudah tidak dihiraukan lagi. Memudarnya semangat gotong royong, solidaritas, kepedulian dan kesetiakawanan sosial sehingga dalam keadaan tertentu seperti musibah, kecelakaan, dan sakit hanya ditangani oleh sebagian kecil orang.Akibatnya, unsur kebersamaan dan kekeluargaan semakin berkurang dan mulai hilang. Sudah banyak dari sebagian orang meniru pola hidup orang barat salah satunya adalah tata cara berpakaian yang identik dengan cara berpakaian yang fullgar dan glamor, sehingga tata cara berpakaian orang timur ( Indonesia ) sudah tidak menjadi tradisi yang harus dilestarikan.

\section{Pergeseran Nilai-nilai Budaya yang Menimbulkan Anomi}

Masuknya unsur-unsur globalisasi yang sangat gencar dalam waktu yang relatif singkat akan mengakibatkan terjadinya perubahan sosial budaya secara susulmenyusul. Sementara itu sistem nilai dan norma yang ada dalam kehidupan masyarakat tidak siap mengantisipasi terjadinya perubahan-perubahan itu. Akibatnya, masyarakat menjadi kebingungan (anomi). Kebingungan masyarakat terhadap terjadinya perubahanperubahan nilai budaya tidak akan berlangsung lama jika masyarakat tersebut dapat menyesuaikan dengan cepat. Hal ini dikhawatirkan akibat anomi ini adalah nilainilai budaya yang telah ada menjadi rusak dan dipengaruhi oleh budaya luar.

\section{Pengertian Kenakalan Remaja}

Fuad Hasan mengatakan bahwa kenakalan ialah perbuatan anti sosial yang dilakukan oleh anak atau remaja yang apabila dilakukan oleh orang dewasa diartikan sebagai kejahatan. Kenakalan merupakan tingkah laku secara ringan yang menyalahi norma dan hukum yang berlaku dalam masyarakat. W.J.S. Poerwadarminta menyatakan bahwa kenakalan ialah perbuatan kurang baik dan mengganggu masyarakat.

Sedangkan remaja adalah suatu usia dimana individu menjadi terintegrasi kedalam masyarakat dewasa, suatu usia dimana anak tidak merasa bahwa dirinya berada dibawah tingkat orang yang lebih tua melainkan merasa sama, (Hurlock, 1991). Sedangkan menurut Hasan Basri (2004: 4), Remaja adalah mereka yang meninggalkan masa kanak-kanak yang penuh dengan ketergantungan dan menuju masa pembentukan tanggung jawab. W.J.S. Poerwadarminta mengatakan bahwa remaja adalah usia mulai dewasa. Berdasarkan penjelasan tersebut diatas dapat penulis simpulkan bahwa remaja adalah suatu usia dimana individu menjadi terintegrasi kedalam masyarakat dewasa dan telah meninggalkan masa kanak-kanak yang penuh dengan tanggung jawab.

Kenakalan remaja adalah semua perbuatan yang merupakan penyelewengan norma-norma kelompok tertentu yang menimbulkan keonaran dalam masyarakat yang dilakukan oleh anak muda, (Ary $\mathrm{H}$. 
Gunawan).Sedangkan menurut Sudarsono, (2008: 11) kenakalan remaja ialah perbuatan, kejahatan, pelanggaran yang dilakukan oleh anak remaja yang bersifat melawan hukum, anti sosial, anti susila, dan menyalahi norma agama. Menurut B. Simanjuntak kenakalan remaja adalah perbuatan dan tingkahlaku yang melanggar terhadap norma-norma hukum pidana dan pelanggaran terhadap kesusilaan yang dilakukan oleh anak-anak.

Berdasarkan penjelasan diatas dapat disimpulkan bahwa kenakalan remaja adalah suatu perbuatan atau tingkah laku yang menyimpang dari norma dan hukum serta anti sosial, kematangan mental, emosi, sosial, fisik masih belum stabil, sehingga dapat menimbulkan keonaran dalam masyarakat.

Menurut Singgih D. Gunarsa (2007:19), Kenakalan remaja dapat digolongkan dalam dua kelompok yang besar, sesuai dengan kaitannya dengan norma hukum yang pertama kenakalan yang bersifat a-moral dan a-sosial dan tidak diatur dalam undang-undang sehingga tidak dapat atau sulit digolongkan pelanggaran hukum. Sedangkan yang kedua kenakalan yang bersifat melanggar hukum dengan penyelesaian sesuai dengan undang-undang dan hukum yang berlaku sama dengan perbuatan melanggar hukum bilamana dilakukan oleh orang dewasa.

\section{Beberapa Tingkah Laku Menyimpang Yang Merupakan Kenakalan Remaja: Perkelahian Antar Pelajar / Remaja}

Perkelahian antar pelajar ( remaja ), sering disebut tawuran antar pelajar, pada mulanya hanya menjadi fenomena yang terdapat pada pelajar-pelajar di kawasan perkotaan. Sekarang ini gejala tawuran ini telah pula menjadi mode bagi pelajar-pelajar yang bersekolah jauh dari perkotaan. Perkelahian baik baik antar dua pelajar maupun antar kelompok-kelompok pelajar merupakan salah satu bentuk perilaku menyimpang. Juga menjadi trend tawuran antar kampung atau desa dan gara-garanya hanya permasalahan yang sepele, misalnya tersinggung karena hanya dipandang, karena masalah joged ketika ada tontonan di desa tersebut, karena pertandingan olah raga antar desa, persoalan rebutan cewek ( pacar ) / kekasih dsb.

\section{Perilaku Seksual}

Menurut W.J.S. Poerwadarminta (1976) menyatakan bahwa perilaku merupakan tanggapan atau reaksi individu yang terwujud dalam gerakan ( sikap ), tidak saja badan atau ucapan. Lebih lanjut dijelaskan bahwa seksual adalah berkenaan dengan seks ( jenis kelamin ) atau berkenaan antara perkara persetubuhan antara laki-laki dan perempuan. Dari penjelasan tersebut dapat disimpulkan bahwa perilaku seksual merupakan sikap atau perbuatan yang menyangkut kebebasan bergaul antara laki laki dan perempuan.

Naluri seksual yang dimiliki manusia merupakan anugerah Tuhan. Keberadaan manusia di bumi ini berlangsung terusmenerus karena dilanjutkan oleh keturunanketurunan baru. Akan tetapi, naluri seksual yang tidak terkendali atau dilakukan tanpa aturan akan mendatangkan kekacauan didalam masyarakat, antara lain adalah berjangkitnya penyakit kelamin, perkelahian, dan kesulitan menentukan orang tua biologis dari anak-anak yang dilahirkan. Selain itu, terjadi pula ancaman yang serius terhadap bayi-bayi yang dilahirkan sehingga berdampak pada pelanggaran hak asasi manusia, seperti aborsi dan pembunuhan bayi-bayi yang lahir dari hubungan bebas tersebut. (Idianto. M, 2004: 161)

Pada era globalisasi kebebasan bergaul dikalangan remaja sudah sangat menghawatirkan, tidak jarang banyak dijumpai para remaja berperilaku menyimpang tanpa memperdulikan masyarakat sekitarnya. Banyak dari sebagian remaja sekarang sudah mulai meniru gaya berpacaran orang luar negeri ( orang barat ) yang identik dengan kebebasan bergaul antara laki - laki dan perempuan, akibatnya banyak remaja saat ini yang putus sekolah karena hamil, banyak remaja sekarang yang menggunakan kemajuan teknologi untuk mengakses hal-hal yang 
tidak benar, mereka menggunakan layanan internet untuk melihat film porno yang memberikan efek negatif terutama pada perilaku dan akhlaknya sehingga bisa menimbulkan perilaku yang menyimpang yang disebut dengan perilaku seksual.

\section{Penyalahgunaan Narkoba}

Secara sosiologis penyalahgunaan narkoba adalah perbuatan yang disadari berdasarkan pengetahuan atau pengalaman sebagai pengaruh langsung maupun tidak langsung dari proses interaksi sosial.Sedangkan secara obyektif penyalahgunaan narkoba merupakan visualisasi dari proses isolasi yang pasti membebani fisik dan mental sehingga dapat menghambat pertumbuhan yang sehat. ecara subjektif individual, penyalahgunaan narkoba oleh kaum remaja sebagai salah satu akselerasi upaya individual agar dapat mengungkap dan menangkap kepuasan yang belum pernah dirasakan dalam kehidupan keluarga yang hakikatnya menjadi kebutuhan primer dan fundamental bagi setiap individu, terutama bagi anak remaja yang sedang tumbuh dan berkembang dalam segala aspek kehidupan.(Sudarsono, 2008: 67). Menurut Sudarsono seseorang yang menderita ketagihan atau ketergantungan pada narkoba akan merugikan diri sendiri, juga merusak kehidupan masyarakat. Sebab secara sosiologis, mereka mengganggu masyarakat dengan perbuatan-perbuatan kekerasan, acuh tak acuh, gangguan lalu lintas, dan kriminalitas.

\section{Tindakan Kriminalitas}

"Crimen" yang berarti kejahatan. Kriminalitas adalah segala sesuatu yang melanggar hukum atau sebuah tindak kejahatan. Soedjono Dirdjosisworo mengatakan bahwa kejahatan adalah perilaku manusia yang melanggar norma (hukum pidana), perbuatan anti sosial yang merugikan, menjengkelkan, menimbulkan korban dan mendapat reaksi dari negara. Secara yuridis, kejahatan dapat didefinisikan sebagai suatu tindakan yang melanggar undang-undang atau ketentuan yang berlaku dan diakui secara legal. Secara sosiologis kejahatan merupakan suatu pola tingkah laku yang merugikan masyarakat (dengan kata lain terdapat korban) dan suatu pola tingkah laku yang mendapatkan reaksi sosial dari masyarakat. Adapun bentuk/tindakan kejahatan yang sering dilakukan adalah penipuan, pencurian, perampokan, pembunuhan dan penggelapan.

\section{Dasar Pandangan Teori Tentang Globalisasi Dengan Kenakalan Remaja}

Globalisasi adalah proses dimana berbagai peristiwa, keputusan dan kegiatan dibelahan dunia yang satu dapat membawa konsekuensi penting bagi berbagai individu dan masyarakat dibelahan dunia yang lain (A.G McGrew, 1992). Sedangkan menurut M. Waters (2004) globalisasi merupakan sebuah proses sosial dimana halanganhalangan bersifat geografis pada tatanan sosial dan budaya semakin menyusut dan setiap orang kian sadar bahwa mereka semakin dekat satu sama lainnya.

Berdasarkan penjelasan tersebut dapat disimpulkan bahwa globalisasi merupakan gejala yang mempengaruhi banyak hal dan tidak bisa dielakan lagi bahwa kehidupan diubah ketika globalisasi masuk dalam kehidupan masyarakat dari tatanan sosial budaya dan dunia seakan tanpa batas,dan dapat menimbulkan dampak salah satunya adalah berkembangnya teknologi informasi dan komunikasi. Fuad Hasan mengatakan bahwa kenakalan ialah perbuatan anti sosial yang dilakukan oleh anak atau remaja yang apabila dilakukan oleh orang dewasa diartikan sebagai kejahatan.Kenakalan merupakan tingkah laku secara ringan yang menyalahi norma dan hukum yang berlaku dalam masyarakat. W.J.S. Poerwadarminta (1976) menyatakan bahwa kenakalan ialah perbuatan kurang baik dan mengganggu masyarakat.

Remaja adalah suatu usia dimana individu menjadi terintegrasi kedalam masyarakat dewasa, suatu usia dimana anak tidak merasa bahwa dirinya berada dibawah tingkat orang yang lebih tua melainkan merasa sama, (Hurlock, 1991). W.J.S. Poerwadarminta (1976) mengatakan bahwa remaja adalah usia mulai dewasa. Kenakalan 
remaja merupakan tingkah laku yang menyimpang dari norma dan hukum serta anti sosial, kematangan mental, emosi, sosial, fisik masih belum stabil, sehingga dapat menimbulkan keonaran dalam masyarakat. Sedangkan menurut Ary $\mathrm{H}$. Gunawan kenakalan remaja adalah semua perbuatan yang merupakan penyelewengan norma-norma kelompok tertentu yang menimbulkan keonaran dalam masyarakat yang dilakukan oleh anak muda, serta menurut Sudarsono (2008) kenakalan remaja ialah perbuatan, kejahatan, pelanggaran yang dilakukan oleh anak remaja yang bersifat melawan hukum, anti sosial, anti susila, dan menyalahi norma agama. Dengan demikian dapat disimpulkan bahwa kenakalan remaja merupakan perbuatan anak-anak yang usianya mulai meranjak dewasa yang melanggar norma sosial, hukum, norma kelompok dan mengganggu ketentraman masyarakat.

\section{Dasar Pandangan Teori Tentang Pengaruh Globalisasi Terhadap Kenakalan Remaja}

Globalisasi merupakan sesuatu hal yang sudah mendunia tanpa ada batas lagi yang memungkinkan akan memberikan dampak yang sangat luas baik dari segi positif maupun negatif. Dengan adanya dampak tersebut seseorang harus menyiapkan mental, terutama dikalangan remaja saat ini, mengingat remaja merupakan usia yang masih labil atau mempunyai mental yang belum stabil, sehingga memerlukan pengawasan dan arahan pada hal-hal yang positif. Seperti halnya dampak dari berkembangnya teknologi informasi, banyak remaja sekarang yang menggunakan kemajuan teknologi untuk mengakses hal-hal yang tidak benar, mereka menggunakan layanan internet untuk melihat film porno yang memberikan efek negatif terutama pada perilaku dan akhlaknya sehingga bisa menimbulkan perilaku yang menyimpang yang disebut dengan perilaku seksual. Dari contoh tersebut perlunya pengawasan dan bimbingan terhadap kalangan remaja, sehingga tidak terjadi perilaku yang menyimpang.

\section{METODE}

\section{Jenis Penelitian}

Dalam melaksanakan suatu penelitian, untuk memperoleh data-data yang dapat dipertanggung jawabkan maka sangatlah perlu sekali menggunakan metode yang tepat dalam pelaksanaan penelitian itu, apabila ingin mendapatkan hasil yang betulbetul ilmiah hendaknya menggunakan metode yang sesuai dengan tujuan yang hendak dicapai. Sebab penelitian tidak akan dapat berjalan dengan baik tanpa mengetahui bagaimana cara yang tepat untuk melaksanakan penelitian itu.

Winarno Surachmad mengatakan bahwa : "metode penelitian adalah cara yang sebaik-baiknya untuk mencapai suatu tujuan dengan menggunakan metode yang efektif." (1980:2). Selanjutnya Kartini Kartono mengatakan bahwa :"Metode penelitian adalah cara berfikir dan berbuat yang dipersiapkan dengan sebaik-baiknya untuk mengadakan penelitian dan untuk mencapai tujuan penelitian" (1983:15-16). Jenis penelitian ini yakni tergolong sebagai $e x$ post facto dengan desain asosiatif.

\section{Waktu dan Tempat Penelitian}

Khususnya untuk penelitian kualitatif, waktu dan tempat penelitian perlu dituliskan secara jelas (untuk penelitian kuantitatif, juga perlu).

\section{Target/Subjek Penelitian}

Dalam menentukan taget penerlian pada penelitian ini mengacu pada pendapat Sutrisno Hadi (1983: 55) yakni menggunakan, Proportional random sampling yakni pengambilan sampel secara random atau tanpa pandang bulu namun teknik random sampling ini bukanlah teknik sembarangan. Proportional random sampling bertitik tolak pada prinsip prinsip matematik yang kokoh karena telah diuji kebenarannya dalam praktek yang mana hasilnya cukup baik. 
Untuk menentukan banyaknya target yang di jadikan sampel, penelitian ini mengacu pada pendapat Winarno Surachmad ( 1975 : 57 ) yang mengemukakan bahwa, “ jika populasi di bawah 100 maka dapat di gunakan sampel sebesar $50 \%$, di bawah 1000 sebesar $25 \%$ dan di atas 1000 sebesar 15\%". Sedangkan menurut Sutrisno Hadi (1983 : 73 ) dikatakan bahwa, "sebenarnya tidak ada suatu ketetapan yang mutlak berapa prosen suatu sampel harus di ambil dari populasi, keadaan ketetapan yang mutlak itu tidak perlu menimbulkan keragu - raguan bagi seorang penyelidik ".

Berdasarkan kedua pendapat tersebut diatas, dapat di tetapkan bahwa, jumlah responden atau sampel yang di ambil dalam penelitian ini sebanyak 100 remaja. Yang terdiri dari usia 16 sampai 30 tahun. Penentuan responden menggunakan metode Proportional Random Sampling Teknik Undian.

\section{Prosedur}

Penelitian ini dilakukan melalui beberapa prosedur seperti : melakukan uji validasi dan reliabilitas instrumen penelitian. Setelah instrumen dinyatakan valid dan reliabel prosedur selanjutnya yakni pengambilan data menggunakan instrumen yang telah di uji, dan dilanjutkan dengan analisis data kemudian hasilnya digunakan untuk penarikan kesimpulan.

\section{Data, Intrumen, dan Teknik Pengumpulan Data}

Metode pengumpulan data adalah metode yang di pakai untuk memperoleh atau mengumpulkan data yang sebaik baiknya. Metode pengumpulan data ini sangat diperlukan dalam mengadakan suatu penelitian, karena berhasil tidaknya penelitian itu tergantung pada metode pengumpulan data yang dipakai. Dalam penelitian ini sengaja menggunakan beberapa teknik untuk mendapatkan data antara lain : Metode Angket; Metode Interview; Metode Dokumenter; Metode Observasi.

\section{Teknik Analisis Data}

Sutrisno Hadi “(1954:1) mengatakan mengolah data berarti menyaring dan mengatur data-data atau informasi yang sudah masuk. Dari pendapat tersebut di atas ,dapat diartikan bahwa, mengolah data adalah merupakan suatu kegiatan tersendiri terhadap data-data yang telah dikumpulkan. Pengertian statistik menurut Paulus Waluyo (1978:2) yakni "Statistik adalah suatu alat, suatu teknik untuk menyimpulkan ,menganalisa dan meringkas bahan-bahan yang berupa angka serta mengambil kesimpulan yang benar dari bahan-bahan yang telah dianalisa “. Dari pendapat tersebut di atas bahwa statistik merupakan suatu teknik pengumpulan data dan penganalisa data yang berupa angka-angka. Adapun yang digunakan untuk menganalisa data dengan menggunakan rumus Chi Kuadrat dengan taraf signifikasi 5\%. Sedangkan untuk rumusannya adalah sebagai berikut :

Keterangan :

$$
X^{2}=\sum \frac{(F o-F h)^{2}}{F h}
$$

$$
\begin{aligned}
& \mathbf{x}^{2} \quad=\text { Chi Kuadrat } \\
& \mathrm{Fo}=\text { frekuensi yang diperoleh } \\
& \mathrm{Fh}=\text { frekuensi yang diharapkan. }
\end{aligned}
$$

Untuk mengetahui besar kecilnya korelasi ,maka perlu diadakan pengetesan dengan menggunakan rumus koefisien kontingensi (KK), adapun rumusannya adalah sebagai berikut :

$$
\mathbf{K K}=\sqrt{\frac{x^{2}}{x^{2}+N}}
$$

Keterangan:

$$
\begin{array}{ll}
\mathrm{KK} & =\text { Koefisien Kontingensi } \\
x^{2} & =\text { Chi Kuadrat } \\
\mathrm{N} & =\text { Jumlah Responden }
\end{array}
$$

Menurut Sutrisno Hadi Koefisien korelasi negatif bergerak antara 1,000 sampai dengan 0,000 dan untuk mengetahui koefisien kontingensi dibuat standart sebagai berikut : 
Citizenship Jurnal Pancasila dan Kewarganegaraan Vol 3 No 1 Maret 2017, hal 121-133

Avaliable online at : http://e-journal.unipma.ac.id/index.php/Citizenship

ISSN: 2302-433X (print) 2579-5740 (online)

$0,000-0,200$ nihil

$0,201-0,400$ korelasi rendah

0,401-0,600 korelasi sedang

0,601-0,800 korelasi cukup

0,801-1,000 korelasi tinggi.

\section{HASIL DAN PEMBAHASAN}

Untuk menganalisis dan sekaligus pengujian hipotesis penelitian ini digunakan analisis statistik dengan rumusan Chi Kuadrat sebagai berikut :

$$
X^{2}=\sum \frac{(f o-f h)^{2}}{f h} \text { dengan } \quad \text { taraf }
$$

signifikasi $\mathbf{5 \%}$

Serta dites dengan rumusan Koefisien Kontingensi, yaitu :

$$
\mathrm{KK}=\sqrt{\frac{x^{2}}{x^{2}+N}}
$$

Sedangkan analisis yang diajukan dalam penelitian ini antara lain adalah sebagai berikut : analisa data dan pengujian mengenai pengaruh globalisasi terhadap kenakalan remaja di desa Sidomukti, jadi berdasarkan data pada tabel 4 , didapat ratarata sebagai berikut :

Rata - rata nilai tentang globalisasi :

$\mathrm{M}=\frac{\Sigma X}{N}=\frac{2429}{100}=24,29$

( Dibawah mean masuk kategori K,diatas mean masuk kategori B ).

Rata - rata nilai tentang kenakalan remaja :

$\mathrm{M}=\frac{\Sigma X}{N}=\frac{2746}{100}=27,46$
( Dibawah mean masuk kategori K,diatas mean masuk kategori B ).

Berdasarkan perhitungan diatas, maka diperoleh jumlah kategori :

a. Baik-baik, sebanyak = 64 remaja

b. Baik-kurang,sebanyak = 1 remaja

c. Kurang-baik, sebanyak $=21$ remaja

d. Kurang - kurang, sebanyak $=14$ remaja

Rumusan frekuensi harapannya adalah :

$f_{h}=\frac{j u m l a h \text { frekuensi baris } \mathrm{x} \text { jumlah frekuensi kolom }}{N}$

a. Baik - baik :

$$
\text { fh a }=\frac{65 \times 85}{100}=\frac{5525}{100}=55,25
$$

b. Baik - kurang :

$$
\text { fh } b=\frac{65 \times 15}{100}=\frac{975}{100}=9,75
$$

c. Kurang-baik :

$$
\text { fh } c=\frac{35 \times 85}{100}=\frac{2975}{100}=29,75
$$

d. Kurang - Kurang :

$$
\text { fh d }=\frac{35 \times 15}{100}=\frac{525}{100}=5,25
$$

Untuk lebih lengkap berikut hasil ringkasan tersaji pada tabel 1 .

Tabel 1. Tabel kerja Pengujian Hipotesis tentang Globalisasi dengan Kenakalan Remaja

\begin{tabular}{|c|c|c|l|c|c|c|}
\hline $\begin{array}{c}\text { Globa- } \\
\text { lisasi }\end{array}$ & $\begin{array}{c}\text { Kenaka- } \\
\text { lan } \\
\text { Remaja }\end{array}$ & $\boldsymbol{f o}$ & $\boldsymbol{f h}$ & $\boldsymbol{f o - f h}$ & ${\text { (fo-fh })^{\mathbf{2}}}^{\frac{(\mathbf{f o - f h})^{2}}{\mathbf{f h}}}$ \\
\hline Baik & $\mathrm{B}$ & 64 & 55,25 & 8,75 & 76,5625 & 1,38 \\
\hline & $\mathrm{K}$ & 1 & 9,75 & $-8,75$ & 76,5625 & 7,85 \\
\hline Kurang & $\mathrm{B}$ & 21 & 29,75 & $-8,75$ & 76,5625 & 2,57 \\
\hline & $\mathrm{K}$ & 14 & 5,25 & 8,75 & 76,5625 & 14,58 \\
\hline Jumlah & & 100 & 100 & 0 & - & 26,38 \\
\hline
\end{tabular}

Sumber : Hasil analisis

Dapat kita lihat pada tabel 1, Berdasarkan $\mathrm{db}=1$ taraf signifikasi $5 \%$ 
didapat nilai $x^{\mathbf{2}}$ tabel $=3,841$. Sedangkan $x^{2}$ hasil perhitungan $=26,38$. Hal ini ternyata $x^{2}$ perhitungan lebih besar dari pada $x^{2}$ tabel, berarti hipotesis nihil yang diajukan ditolak, jadi signifikan.

Sedangkan untuk mengetahui besar kecilnya korelasi, maka nilai $x^{\mathbf{2}}$ dites dengan rumus koefisien kontingensi ( KK ) sebagai berikut :

$$
\begin{aligned}
\mathrm{KK} & =\sqrt{\frac{x^{2}}{x^{2}+N}} \\
& =\sqrt{\frac{26,38}{26,38+100}} \\
& =\sqrt{\frac{26,38}{126,38}}=\sqrt{0,208735559} \\
& =0,456
\end{aligned}
$$

Nilai KK yang diperoleh adalah 0,456 ternyata bergerak antara 0,401 0,600 , maka pengaruh yang didapat memiliki korelasi yang sedang, dapat disimpulkan bahwa,"Ada pengaruh globalisasi terhadap kenakalan remaja di desa Sidomukti Kecamatan Mayang Tahun 2016, dengan korelasi sedang.

Dari hasil analisis data dapat diketahui bahwa karena hipotesis nihil ditolak sehingga hipotesis kerja yang diterima, ini berarti ada pengaruh globalisasi terhadap kenakalan remaja di desa Sidomukti Kecamatan Mayang, dengan kategori sedang. Pernyataan tersebut didukung oleh data - data sebagai berikut : $x^{2}=26,38 ; \mathrm{KK}$ $=0,456$.

Dengan demikian maka dapat dilihat bahwa remaja yang memanfaatkan berkembangnya atau dampak dari globalisasi untuk hal - hal yang positif, tentu kenakalan atau perilaku yang menyimpang tidak akan terjadi, sehingga perilakunya baik, tetapi bagi siswa yang menyalahgunakan dampak dari globalisasi salah satunya adalah berkembangnya teknologi informasi dan komunikasi untuk hal - hal yang negatif, maka kenakalan atau perilaku yang menyimpang akan terjadi, sehingga perilaku kurang baik. Tetapi hal tersebut bisa terjadi sebaliknya pula karena masih banyak dari sebagian siswa meskipun telah memanfaatkan dampak dari globalisasi untuk hal-hal yang positif, tetapi kenakalan atau perilaku yang menyimpang masih terjadi, hal ini bisa terjadi mengingat kompleknya faktor yang mempengaruhi kehidupan remaja, salah satunya adalah dampak dari globalisasi yang menyangkut berkembangnya teknologi informasi dan komunikasi, disamping itu karena penelitian ini hanya berdasarkan data nilai angket yang didukung dengan interview

\section{SIMPULAN DAN SARAN}

\section{Simpulan}

Berdasarkan hasil penelitian dalam analisa data yang menggunakan rumus Chi Kuadrat dan dites menggunakan rumus koefisien korelasi ( KK ), dapat disimpulkan bahwa : Ada pengaruh globalisasi terhadap kenakalan remaja di desa Sidomukti Kecamatan Mayang Tahun 2016.

\section{Saran}

Perhatian dari orang tua khususnya keluarga dan para tokoh masyarakat sangatlah penting untuk selalu memotivasi remaja baik remaja awal, tengah dan akhir pada hal - hal yang positif, serta selalu memberikan arahan, agar remaja terutama remaja awal agar memiliki dasar kepribadian yang kuat terutama peletakan dasar-dasar religiu agar tidak melakukan tindakan atau perilaku yang menyimpang akibat kemajuian teknologi dan informasi. Hendaknya setiap remaja dapat mengatur perilaku dan selalu memfokuskan diri pada hal - hal yang positif, sehingga tidak melakukan tindakan yang melanggar normanoram yang disepakati oleh masyarakat di desa Sidomukti, serta dapat meningkatkan inovatif dan kreatifitas melalui wadah karang taruna. 
Citizenship Jurnal Pancasila dan Kewarganegaraan Vol 3 No 1 Maret 2017, hal 121-133

Avaliable online at : http://e-journal.unipma.ac.id/index.php/Citizenship ISSN: 2302-433X (print) 2579-5740 (online)

\section{DAFTAR PUSTAKA}

Abu Achmadi. 2009, Metodologi Penelitian. Jakarta: PT. Bumi Aksara.

Aim Abdulkarim. 2007, Kewarganegaraan SMA kelas XII. Bandung: PT. Grafindo Media Pratama.

Basri, Hasan. 2004. Remaja Berkualitas; Problematika Remaja Dan Solusinya. Yogyakarta: Mitra Pustaka.

Budiyanto. 2005. Kewarganegaraan SMA kelas XII. Jakarta: PT. Erlangga.

Idianto M. 2004. Sosiologi SMA kelas X. Jakarta: PT. Erlangga.

Singgih D. Gunarsa. 2007. Psikologi Remaja. Jakarta: PT. Gunung Mulia.

Sudarsono. 2008. Kenakalan Remaja. Jakarta: PT. Rineka Cipta.

Suharsimi Arikunto. 2006, Prosedur Penelitian; Suatu Pendekatan Praktik. Jakarta: PT. Rineka Cipta.
Suharsimi Arikunto. 2009, Manajemen Penelitian. Jakarta: PT. Rineka Cipta.

Sujiyanto. 2007. Praktik Belajar Kewarganegaraaan SMA kelas XII. Jakarta: Ganeca Exact.

Sumiharsono, Rudy. 2009. Metodologi Penelitian. Jember: IKIP PGRI.

Sumiharsono, Rudy. 2009. Pedoman Penulisan Karya Ilmiah. Jember: IKIP PGRI.

Sumiharsono, Rudy. 2008. Statistik Pendidikan. Jember: IKIP PGRI.

2009. UU sisdiknas. Bandung: PT. Fokos Media.

W. J. S. Poerwadarminta, 1976, Kamus Umum Bahasa Indonesia, Pusat pembinaan dan Pengembangan Bahasa Departemen Pendidikan dan Kebudayaan, Jakarta. 